\title{
Corticotropin-releasing hormone inhibits progesterone production in cultured human placental trophoblasts
}

\author{
Ruifang Yang*, Xingji You*, Xiaolu Tang, Lu Gao and Xin Ni \\ Department of Physiology, Second Military Medical University, 800 Xiangyin Road, Shanghai 200433, People's Republic of China \\ (Requests for offprints should be addressed to X Ni; Email: nxljq2003@yahoo.com.cn) \\ *(R Yang and $X$ You contributed equally to this work)
}

\begin{abstract}
Placental-derived corticotropin-releasing hormone $(\mathrm{CRH})$ seems to play a major role in the mechanisms controlling human pregnancy and parturition. It has been suggested that $\mathrm{CRH}$ directly modulates the endocrine function of placental trophoblasts, including the production of estrogen, $\mathrm{ACTH}$, and prostaglandin. In this study, we sought to investigate the effect of $\mathrm{CRH}$, locally produced by placenta, on progesterone production. Percoll-purified placental trophoblasts were obtained from uncomplicated term pregnancies and cultured for $72 \mathrm{~h}$. Progesterone concentration in culture media was measured by RIA. The mRNA transcripts encoding CYP11A1 and HSD3B1, the enzymes for progesterone synthesis, were determined by quantitative real-time reverse transcription (RT)-PCR. Results showed that $\mathrm{CRH}\left(10^{-8}-10^{-6} \mathrm{~mol} / \mathrm{l}\right)$ caused a significant decrease in progesterone levels in a dose-dependent manner. The $\mathrm{CRH}$ antagonist, $\alpha$-helical $\mathrm{CRH}$ $9-41$, at $10^{-7}-10^{-5} \mathrm{~mol} / \mathrm{l}$ stimulated progesterone secretion. Consistent with this thesis, $\mathrm{CRH}$ decreased, whereas $\alpha$-helical $\mathrm{CRH}$ increased, the mRNA levels of CYP11A1 and HSD3B1. Since CRH has been shown to activate the phospholipase C-protein kinase C (PKC) signal pathway in placenta, we examined whether the effect of $\mathrm{CRH}$ on progesterone synthesis was dependent on PKC signal pathway. Treatment of cells with PKC inhibitor, Gö6976, resulted in a significant increase in progesterone production, and exogenous $\mathrm{CRH}$ restored progesterone production. In conclusion, placental $\mathrm{CRH}$ exhibits a tonic inhibitory effect on progesterone production in a PKC-dependent fashion.
\end{abstract}

Journal of Molecular Endocrinology (2006) 37, 533-540

\section{Introduction}

Progesterone, as its name implies is a pro-gestation hormone. Early in human pregnancy, progesterone is produced mainly by the persistent corpus luteum. After about 6-8 weeks of pregnancy, luteal production of progesterone declines as a result of diminished human chorionic gonadotropin (HCG) production by the placenta, and the placental trophoblasts take over as the main source of progesterone production (Tuckey 2005). Placental progesterone continues to increase up to term when the placenta is lost following parturition (Mesiano 2001). The essential role of progesterone in maintaining pregnancy is unequivocal and remarkably universal. In all mammals so far, it has been shown that pregnancy cannot exist in the complete absence of progesterone. It has been shown that disruption of progesterone synthesis initiates myometrial contractions or labor and delivery at all stages of pregnancy (Selinger et al. 1987, Haluska et al. 1997). Progesterone can be synthesized from cholesterol by the syncytiotrophoblast (Tuckey 2005). A variety of endogenous factors such as estrogen, HCG, and cyclic AMP are known to regulate placental progesterone production (Feinman et al. 1986, Rodway et al. 1988, Chaudhary et al. 1992). Thus, further study of the mechanism by which the hormone network controls progesterone production in placenta is a prerequisite to gain insight into the mechanism of pregnancy and parturition.

Corticotropin-releasing hormone (CRH) appears to be a key element in the control of the maintenance of human pregnancy and parturition. During human pregnancy, CRH is expressed by fetomaternal tissues and the concentration of CRH peptide and mRNA in the placenta increases with advancing gestation, in parallel with exponential increase in maternal plasma CRH concentrations (Sasaki et al. 1987, Riley et al. 1991). The rise in maternal CRH level occurs earlier and more rapidly in women who deliver preterm (McLean et al. 1995, Wadhwa et al. 1998), and more slowly in women who deliver postterm, than in women who deliver at term (McLean et al. 1995). Previous in vitro studies showed that CRH stimulated adrenocorticotrophic hormone (ACTH) and prostaglandin (PG) production in placenta and fetal membrane and enhanced $\mathrm{PGF}_{2 \alpha}$ and oxytocin-mediated myometrial contractility (Petraglia et al. 1987, Quartero \& Fry 1989, Jones \& Challis 1990, Florio et al. 1996). CRH may directly stimulate cortisol and dehydroepiandrostenedione sulfate (DHEAS) production from fetal adrenals at the end of pregnancy, which promotes the 
myometrial activation at this time (Smith et al. 1998, Sirianni et al. 2005a,b). Thus, it has been suggested that $\mathrm{CRH}$ is involved in the mechanisms that determine the duration of gestation and the onset of parturition.

Two major CRH receptor subtypes are recognized, CRH-R1 and CRH-R2, which belong to the class II G-protein-coupled receptor superfamily. The human placenta has been shown to express both subtypes of CRH receptors (Florio et al. 2000). More recently, Jeschke and colleagues showed that the addition of CRH to the placental trophoblast cultures resulted in a decrease in progesterone release (Jeschke et al. 2005). However, the effect of CRH produced locally in the placental trophoblasts on progesterone biosynthesis, and a detailed and quantitative analysis of the effects of $\mathrm{CRH}$ on all the enzymes needed for progesterone production as well as the specific CRH receptors responsible for the actions of CRH have not been performed. Therefore, in the present study, we conducted experiments to determine the effects of exogenous and endogenous CRH on progesterone production in placental cells and, quantitatively, the effect of CRH on mRNA levels of all the enzymes needed for progesterone production.

\section{Materials and methods}

\section{Human placental cell culture}

Human term placentae were obtained from normal term pregnancies after elective cesarean section. None of the patients had received prostaglandins, glucocorticoids, or oxytocin. Collections of placentae were performed with the approval of Changhai Hospital human ethics committee. Cytotrophoblasts were isolated and cultured according to a slightly modified Kliman's method as described previously (Kliman et al. 1986, Ni et al. 1997). Briefly, approximately $60 \mathrm{~g}$ chorionic villi tissue were obtained from the maternal side of the placenta, digested with $0 \cdot 125 \%$ trypsin (Life Technologies, Inc.) and $0.02 \%$ DNase-I (Sigma) in phenol red-free DMEM (Sigma), thrice for $30 \mathrm{~min}$ each. The dispersed cells were filtered with $200 \mu \mathrm{m}$ nylon gauze and loaded onto a discontinued Percoll (Amersham Biosciences) gradient (5-70\%), then centrifuged at $2300 \mathrm{~g}$ for $20 \mathrm{~min}$. The cytotrophoblast cells between a density of 1.049 and $1.062 \mathrm{~g} / \mathrm{ml}$ were collected, then plated onto 12-well plates at a density of $1 \cdot 2 \times 10^{6}$ / well and grown in a phenol red-free DMEM with $10 \%$ charcoal-stripped fetal calf serum at $37{ }^{\circ} \mathrm{C}$ in $5 \% \mathrm{CO}_{2}-95 \%$ air for $72 \mathrm{~h}$. The DMEM serum-free medium was then used to replace the culture medium. The hormones and antagonists were added and incubated for $24 \mathrm{~h}$ or for different time periods. At the end of the experiment, representative wells of cells were fixed and immunostained for cytokeratin and vimentin using primary antibodies (Santa Cruz Biotechnology, Inc., Santa Cruz, CA, USA) to assess cell purity (Kliman et al. 1986).

CRH and $\alpha$-helical CRH 9-41 were purchased from Sigma Chemical Co. (Sigma). Substances were used at final concentrations ranging from $10^{-9}$ to $10^{-5} \mathrm{M}$, in order to embrace the maternal or intrauterine tissue concentrations found in human pregnancy at term. Vehicle-treated wells (controls) were present in each experiment. Each treatment was performed in quadruplicate for each preparation of cells. After incubation, the medium was harvested and stored at $-20{ }^{\circ} \mathrm{C}$ until progesterone assay. Cells were used for RNA extraction. A well of cells in each treatment was used to assess the cell viability by MTT assay (Mosmann 1983). The assay depends on the reduction of the tetrazolium salt MTT (3-[4,5-dimethylthiazol-2-yl]-2,5-diphenyl tetrazolium bromide; Sigma Chemical Co.) by functional mitochondria to formazan. After a 2-h incubation at $37{ }^{\circ} \mathrm{C}$ with MTT, the cells were lysed with dimethyl sulfoxide in Sorensen's glycine buffer and the formazan crystals solubilized. Absorbance was read at $550 \mathrm{~nm}$ using a spectrophotometric microplate reader.

\section{Hormone assays}

Progesterone was assayed using commercially available RIA kits (Shanghai Institute of Biological Product, Shanghai, China). The mean intra- and interassay coefficients of variation were 4.4 and $6.9 \%$ respectively (manufacture's data).

CRH immunoreactivity in the culture media was assayed by RIA performed as previously described (Ni et al. 1997).

\section{Total RNA extraction and quantitative real-time RT-PCR}

Total RNA was isolated by using TRIzol reagent according to the manufacturer's instructions (Invitrogen). First-strand cDNA was synthesized from $1 \mu \mathrm{g}$ RNA with oligo(dT) 12-18 primer using superscript first-strand synthesis kit (Invitrogen) according to the manufacturer's instruction. For every RT reaction set, one RNA sample was set up without reverse transcriptase enzyme to provide a negative control. Quantitative realtime PCR (QT-RT-PCR) analysis was carried out using Rotor Gene 3000 (Corbett Research, Sydney, Australia). Reverse-transcription products (cDNA) were diluted for subsequent QT-RT-PCR. QT-RT-PCR solution consisted of $2 \cdot 0 \mu \mathrm{l}$ diluted cDNA product, $0 \cdot 2 \mu \mathrm{M}$ of each paired primer, $2 \cdot 0 \mathrm{mM} \mathrm{Mg}^{2+}, 100 \mu \mathrm{M}$ deoxynucleotide triphosphates, 2 U Taq DNA polymerase, and $1 \times$ PCR buffer. SYBR green I (BMA, Rockland, ME, USA) was used as 
detection dye. The nucleotide sequences of the primers are shown in Table 1 . The specificity of the primers was verified by examining the melting curve as well as subsequent sequencing of the QT-RT-PCR products.

To determine the relative quantitation of gene expression for both target and housekeeping genes, the relative standard curves method was used (Corbett Research). Briefly, standard curves for GAPDH, CYP11A1, and $H S D 3 B 1$ were constructed by performing a dilution series of the untreated control cDNA. For each RNA sample, the relative amounts of $G A P D H$, CYP11A1, and HSD3B1 mRNA were obtained, and the ratios of CYP11A1 mRNA to GAPDH mRNA and $H S D 3 B 1$ mRNA to GAPDH mRNA were calculated. For each experiment, the amount of CYP11A1 or HSD3B1 mRNA under various treatment conditions is expressed relative to the amount of transcript present in the untreated control.

\section{Statistical analyses}

The values are expressed as means \pm s.D. Statistical analyses were carried out using one-way ANOVA followed by Student-Newman-Keulus test. Significance was set at $P<0 \cdot 05$.

\section{Results}

\section{Cell morphology}

At the end of the culture period, placental trophoblast cells tended to form aggregates, thought to correspond to syncytium formation in vivo. These cells were predominately cytokeratin-positive $(>90 \%)$ and vimentin-negative.

\section{Concentration and time-dependent effects of CRH on progesterone production}

After placenta trophoblast cells were cultured for $72 \mathrm{~h}$, they were treated with increasing concentrations of CRH $\left(10^{-9}-10^{-6} \mathrm{M}\right)$ for $24 \mathrm{~h}$; media content of progesterone was determined by RIA. CRH caused a concentration-dependent decrease in progesterone production, with significant inhibition seen at the dose of $10^{-8}-10^{-6} \mathrm{~mol} / 1$ (Fig. 1A). The maximal effect was achieved at $10^{-6} \mathrm{~mol} / \mathrm{l}$, which caused a $76 \%$ decrease in progesterone production. The time course of placental cell response to treatment with CRH $\left(10^{-7} \mathrm{M}\right)$ is shown in Fig. 1B. A significant decrease was seen after $6 \mathrm{~h}$ treatment $(P<0 \cdot 05)$ and maximal inhibition was obtained after $24 \mathrm{~h}$ treatment $(P<0 \cdot 01$; Fig. 1B).

In human placenta, the synthesis of progesterone depends principally on CYP11A1 and HSD3B1 (Tuckey 2005). In order to investigate the effect of CRH on the expression of CYP11A1 and HSD3B1, we measured the mRNA encoding CYP11A1 and HSD3B1 in placental cells by quantitative real-time RT-PCR. The melting curve of quantitative real-time PCR showed a single peak of melting temperature value for PCR products of CYP11A1 and HSD $3 B 1$ respectively (data not shown). Sequence analysis of CYP11A1 and HSD3B1 PCR products showed complete alignment with the corresponding sequences of human CYP11A1 and HSD 3B1 gene in the gene bank (data not shown).

As shown in Fig. 2, CRH $\left(10^{-8}-10^{-6} \mathrm{~mol} / \mathrm{l}\right)$ induced a significant decrease in CYP11A1 and HSD $3 B 1$ mRNA levels in a dose-dependent manner. Maximal effect was achieved at a concentration of $10^{-6} \mathrm{~mol} / \mathrm{l}$, which caused about 69 and $68 \%$ reduction of CYP11A1 and HSD3B1 mRNA expression respectively. Time-course analysis revealed that the significant decreases in CYP11A1 and HSD3B1 mRNA were achieved by $10^{-7} \mathrm{~mol} / \mathrm{l} \mathrm{CRH}$ at $6 \mathrm{~h}$. At $24 \mathrm{~h}, 10^{-7} \mathrm{~mol} / 1 \mathrm{CRH}$ produced a $50 \%$ decrease in CYP11A1 mRNA level and a $52 \%$ decrease in $H S D 3 B 1$ mRNA level.

At the end of each experiment, cell viability was assessed by MTT assay. There were no differences between the cells of each treatment (data not shown).

\section{Effect of CRH receptor antagonist on progesterone production}

It is known that placental trophoblast cells can produce CRH endogenously ( $\mathrm{Ni}$ et al. 1997). We measured the level of CRH in the culture media of control cells by RIA. The contents of CRH in culture media were 297.67

Table 1 RT-PCR oligonucleotide primers used for the study

\section{Primer sequence}

\author{
Gene \\ HSD3B1 (299 bp) \\ CYP11A1 (344 bp) \\ GAPDH (189 bp)
}

Sense: 5'-CGTCTCGGTCATCATCCACA-3'

Antisense: 5'-TCAGATTCCACCCGTTAGCC-3'

Sense: 5'-TGGCTGAGCAAAGACAAGAACA-3'

Antisense: $5^{\prime}$-GAGCAGGACTTGGGACAGACGA- $3^{\prime}$

Sense: 5'-GACACCCACTCCTCCACCTTTGA-3'

Antisense: 5'-CTCTCTTCCTCTTGTGCTCTTGC-3' 

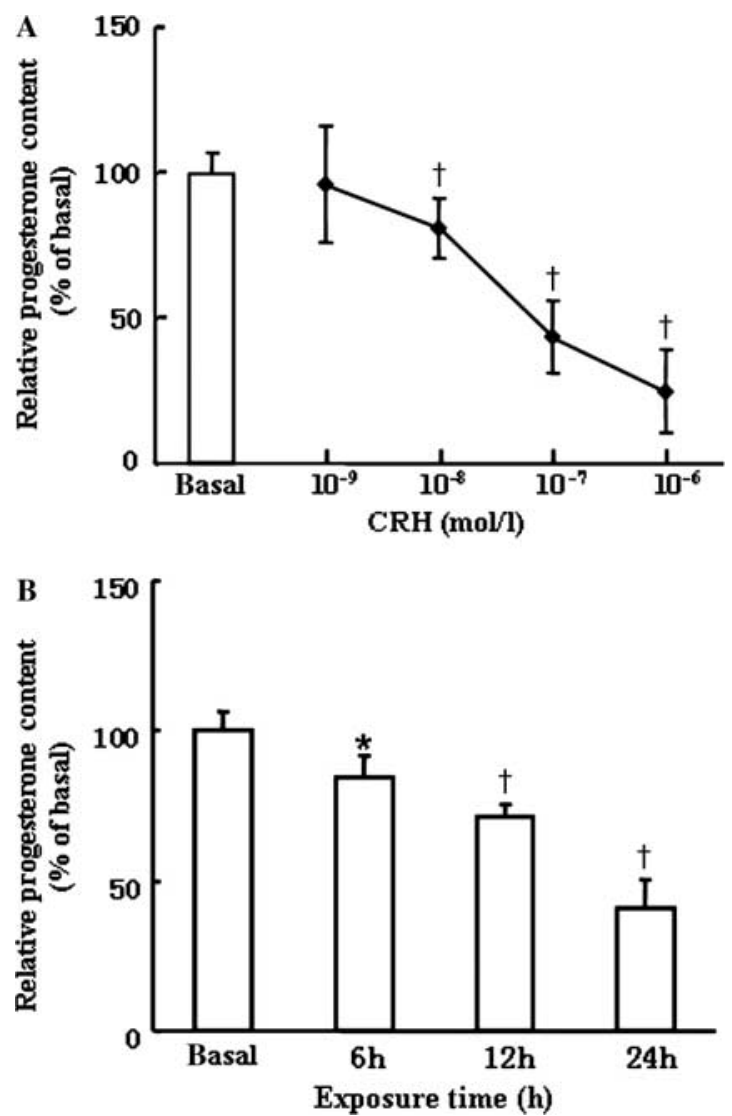

Figure 1 Concentration- and time-dependent effects of $\mathrm{CRH}$ on progesterone production in placental trophoblast cells. Placental cells were treated with indicated concentrations of $\mathrm{CRH}$ for $24 \mathrm{~h}$ (A). Cells were incubated for the indicated times with $\mathrm{CRH}$ $\left(10^{-7} \mathrm{~mol} / \mathrm{l}\right)(\mathrm{B})$. Progesterone levels in culture media were assayed by RIA. Values are presented as mean percentage control \pm S.D. for total of seven experiments $(n=6)$ performed in triplicate. ${ }^{\star} P<0.05,{ }^{\dagger} P<0.01$ compared with vehicle controls.

$(64 \mathrm{pM}) \pm 40 \cdot 47 \mathrm{pg} / \mathrm{ml}$ after a 3 -h incubation period. To block the effects of endogenous $\mathrm{CRH}$, cells were treated with increasing concentrations of the CRH receptor antagonist $\alpha$-helical CRH 9-41, which, at $10^{-7}-10^{-5} \mathrm{~mol} / \mathrm{l}$, resulted in a dose-dependent increase in progesterone production, to approximately $196 \%$ of the control value at a concentration of $10^{-5} \mathrm{~mol} / \mathrm{l}$ after a 24 -h treatment period (Fig. 3A). Addition of exogenous CRH reversed the increase in progesterone production caused by the addition of $\alpha$-helical CRH 9-41, to a value that was decreased significantly, compared with cells treated with $\alpha$-helical CRH 9-41 alone (Fig. 3B).

As shown in Fig. 4, $\alpha$-helical CRH 9-41 $\left(10^{-7}-10^{-5}\right.$ mol/l) induced a significant increase in CYP11A1 and $H S D 3 B 1$ mRNA levels in a dose-dependent manner, to approximately $91 \%$ increase in CYP11A1 mRNA and $92 \%$ increase in $H S D 3 B 1$ mRNA at a concentration of
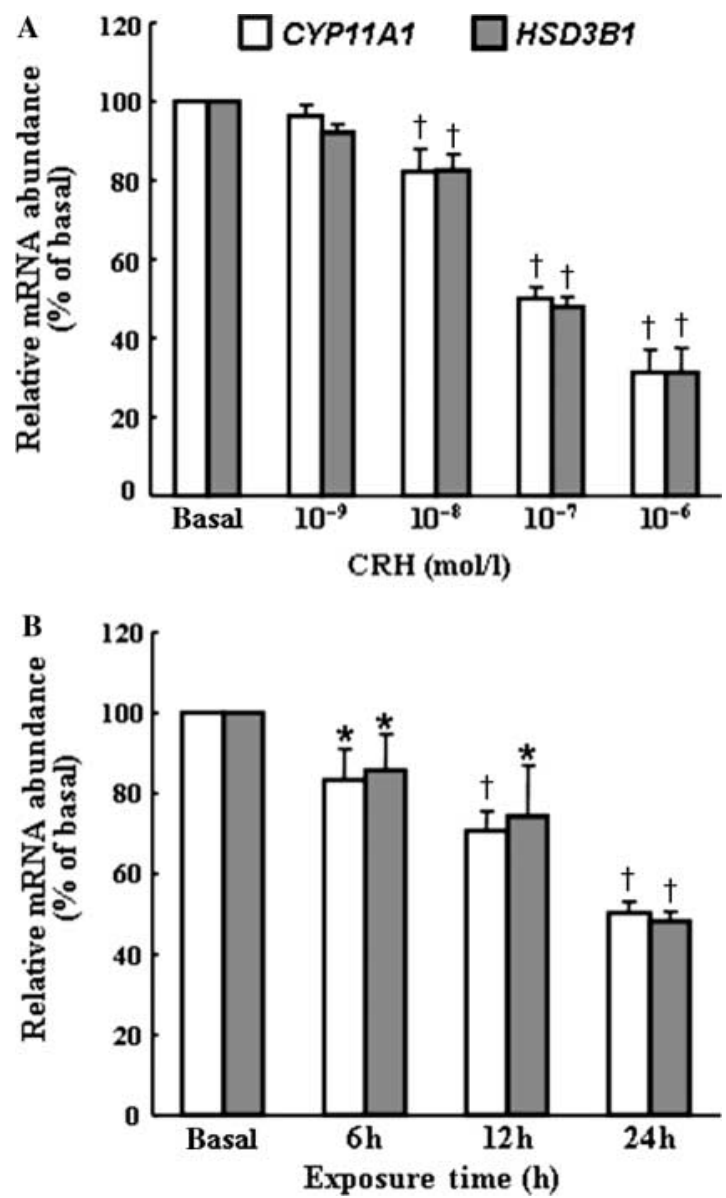

Figure 2 Concentration- and time-dependent effects of $\mathrm{CRH}$ on CYP11A1 and HSD3B1 transcript levels in placental trophoblast cells. Real-time RT-PCR was used to quantify mRNA levels of CYP11A1 and HSD3B1 in placental trophoblasts. (A) Cells were treated with the indicated concentrations of $\mathrm{CRH}$ for $24 \mathrm{~h}$. (B) Cells were incubated for the indicated times with $\mathrm{CRH}\left(10^{-7}\right.$ $\mathrm{mol} / \mathrm{l})$. Data points are the values calculated as described in Materials and methods and are presented as mean percent control \pm S.D. for a total of six experiments $(n=6)$ performed in triplicate. ${ }^{\star} P<0.05,{ }^{\dagger} P<0.01$ compared with basal.

$10^{-5} \mathrm{~mol} / \mathrm{l}$. These effects can also be reversed by the addition of exogenous CRH.

\section{Effect of PKC inhibitor on progesterone production}

Treatment of placental cells with a protein kinase $\mathrm{C}$ (PKC) inhibitor Gö6976 (10 $\left.0^{-7}-10^{-9} \mathrm{~mol} / \mathrm{l}\right)$ significantly increased progesterone production in a dosedependent manner. Maximal effect was obtained at the concentration of $10^{-7} \mathrm{~mol} / \mathrm{l}$, which caused $84 \%$ increase in progesterone production. The concentration of $10^{-7} \mathrm{~mol} / \mathrm{l} \mathrm{CRH}$ reversed the stimulatory effects of $10^{-8}$ or $10^{-9} \mathrm{~mol} / 1$ Gö69769 on progesterone production (Fig. 5A). 
A

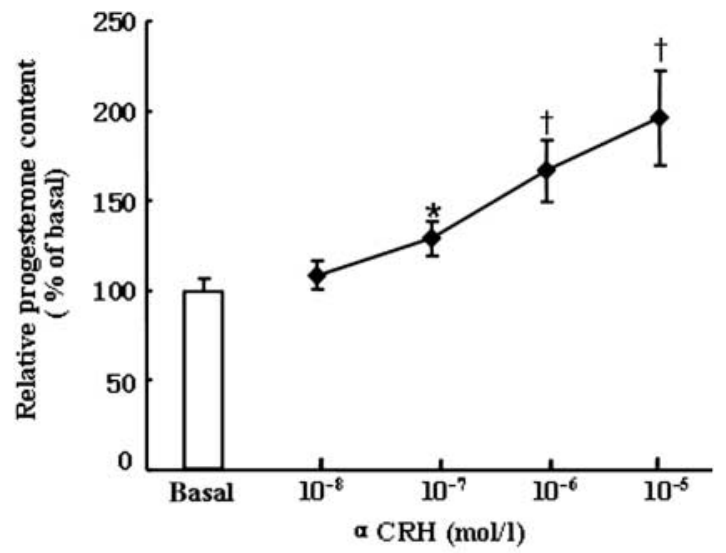

B

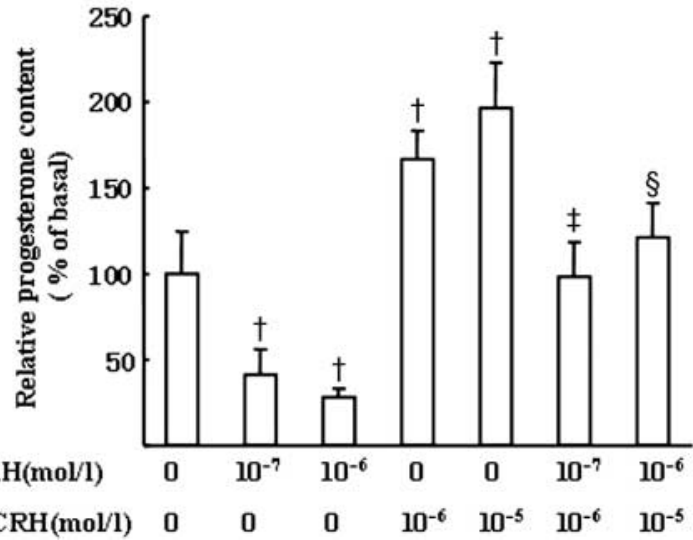

Figure 3 Effects of $\alpha$-helical CRH $9-41$ on progesterone production in placental trophoblasts. (A) Cells were incubated with increasing concentrations of $\alpha$-helical CRH 9-41 for $24 \mathrm{~h}$. (B) Cells were treated with indicated concentrations of $\mathrm{CRH}, \alpha$-helical $\mathrm{CRH}$ 9-41, and $\mathrm{CRH}$ plus $\alpha$-helical CRH 9-41 for $24 \mathrm{~h}$. Values are presented as mean percent control \pm S.D. for a total of five experiments performed in triplicate. $\alpha \mathrm{CRH}, \alpha$-helical CRH 9-41; ${ }^{*} P<0.05$, ${ }^{\dagger} P<0.01$ compared with vehicle controls; ${ }^{\ddagger} P<0.01$ vs $\mathrm{CRH} 10^{-7}$ $\mathrm{mol} / / ;{ }^{\S} P<0.01 \mathrm{vs} \mathrm{CRH} 10^{-6} \mathrm{~mol} / \mathrm{l}$.

Consistently, Gö6976 (10 $\left.10^{-7}-10^{-9} \mathrm{~mol} / \mathrm{l}\right)$ significantly increased CYP11A1 and HSD3B1 mRNA levels. The maximal effect was achieved at a dose of $10^{-7} \mathrm{~mol} / \mathrm{l}$ Gö6976, which caused about a $71 \%$ increase in CYP11A1 mRNA and a $69 \%$ increase in $H S D 3 B 1$ mRNA. Addition of exogenous CRH $\left(10^{-7} \mathrm{~mol} / \mathrm{l}\right)$ reversed the increases in CYP11A1 and HSD 3B1 mRNA caused by the addition of Gö6976 $\left(10^{-8}-10^{-9} \mathrm{~mol} / \mathrm{l}\right)$, to a value that was decreased significantly, compared with cells treated with Gö6976 alone (Fig. 5B).

\section{Discussions}

In this study, we have demonstrated that treatment of cultured syncytiotrophoblast with CRH significantly decreased progesterone production in a dose-dependent pattern. When CRH receptors were blocked by the
A
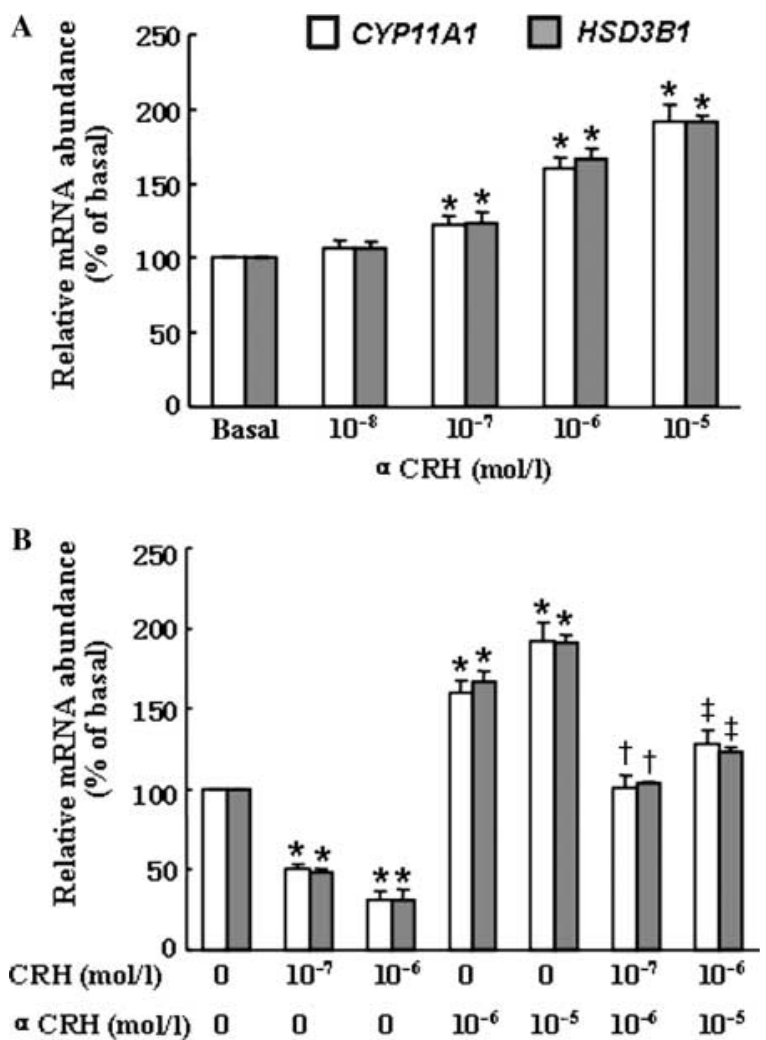

Figure 4 Effects of $\alpha$-helical CRH 9-41 on CYP11A1 and HSD3B1 transcript levels in placental trophoblasts. (A) Cells were incubated with increasing concentrations of $\alpha$-helical CRH 9-41 $(\alpha \mathrm{CRH})$ for $24 \mathrm{~h}$. (B) Cells were treated with indicated concentrations of $\mathrm{CRH}, \alpha$-helical CRH 9-41 ( $\alpha \mathrm{CRH})$, and CRH plus $\alpha$-helical CRH 9-41 $(\alpha \mathrm{CRH})$ for $24 \mathrm{~h}$. Data points are the values calculated as described in Materials and methods and are presented as mean percent control \pm S.D. for a total of five experiments performed in triplicate. ${ }^{\star} P<0.01$ compared with vehicle controls. ${ }^{\dagger} P<0.01$ vs $\mathrm{CRH} 10^{-7} \mathrm{~mol} / / ;{ }^{\ddagger} P<0.01$ vs $\mathrm{CRH}$ $10^{-6} \mathrm{~mol} / \mathrm{l}$.

administration of CRH receptor antagonist, there was a significant increase in progesterone concentration in the culture media. Progesterone production in placental cells was significantly increased when PKC activity was inhibited, and this increase could be reversed by the addition of exogenous CRH. We have also found that CRH inhibited the expression of the mRNA encoding the enzymes that comprise the progesterone biosynthesis pathway. These data support the hypothesis that CRH may act through a PKC-dependent pathway to inhibit progesterone production in placental cells throughout gestation.

The placental cells endogenously produced not only CRH (Sun et al. 1994, Ni et al. 1997), but also CRHrelated peptides including urocortin, urocortin II, and urocortin III (Clifton et al. 2000, Karteris et al. 2005). These peptides bind to the CRH receptors within the placenta. Our results showed that the significant effect 

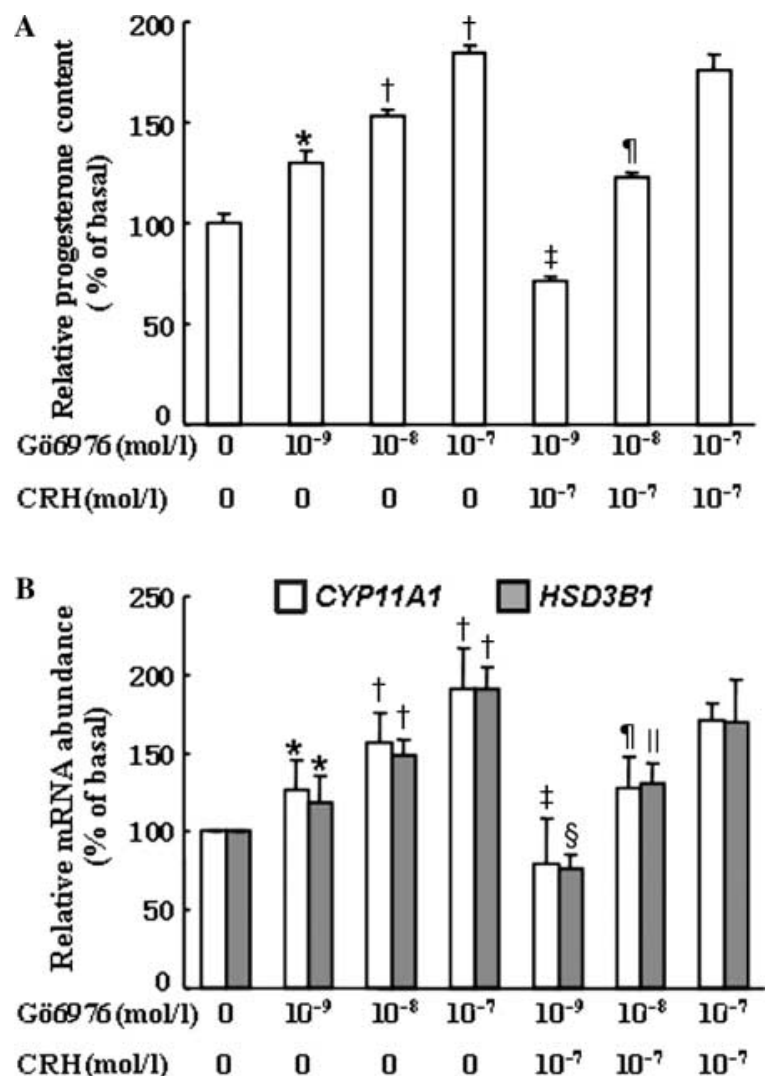

Figure 5 Effects of Gö6976 treatment on progesterone production and expression of CYP11A1 and HSD3B1 mRNA. Cells were treated with indicated concentrations of Gö6976, and $\mathrm{CRH}$ plus Gö6976 for 24 h. (A) Progesterone levels in culture media were assayed by RIA. (B) Real-time RT-PCR was used to quantify mRNA levels of $C Y P 11 A 1$ and $H S D 3 B 1$ in placental trophoblasts. Data points are the values calculated as described in Materials and methods and are presented as mean percent control \pm s.D. for a total of five experiments $(n=5)$ performed in triplicates. ${ }^{*} \bar{P}<0.05$, ${ }^{\dagger} P<0.01$ compared with vehicle controls. ${ }^{\ddagger} P<0.05,{ }^{\S} P<0.01$ vs Gö6976 $10^{-9} \mathrm{~mol} / /$; " $P<0.05$, " $P<0.01$ vs Gö6976 $10^{-8} \mathrm{~mol} / \mathrm{l}$.

of CRH on progesterone production occurred at the concentration of $10^{-8} \mathrm{~mol} / \mathrm{l}$, which is higher than CRH level in maternal plasma at term (McLean et al. 1995), most probably because the placental cells secrete CRH and CRH-related peptides. Therefore, we administered a specific CRH receptor antagonist, $\alpha$-helical CRH 9-41, to block the CRH receptors in placental cells. It resulted in an increase in progesterone production in a dosedependent manner, and this increase could be reversed by the addition of exogenous CRH. The human placental trophoblasts have been shown to express CRH-R1 $\alpha$, CRH-R1 $\beta$, variant CRH-R1c, and CRH-R2 $\beta$ (Grammatopoulos et al. 1999, Florio et al. 2000, Karteris et al. 2000). In the current study, we were unable to determine which receptor subtype was responsible for these effects on progesterone production. Our evidence, combined with the demonstrated expression of
CRH by placenta (Sasaki et al. 1987, Riley et al. 1991) and of CRH receptor subtypes in these tissues (Grammatopoulos et al. 1999, Florio et al. 2000, Karteris et al. 2000), leads us to suggest a paracrine/autocrine role for CRH in the regulation of progesterone production in vivo. Study conducted on primary cultures of granulose-lutein cells of human ovary revealed that CRH significantly inhibited progesterone production through a paracrine/autocrine pathway (Ghizzoni et al. 1997).

Karteris et al. have demonstrated that, within the placenta, CRH receptors may be coupled to the $\alpha$-subunit of $\mathrm{Gq}$ and can also activate $\mathrm{Go}$ and $\mathrm{Gz}$, but not Gs and Gi. However, the way in which CRH activates Go and Gz in the placenta is not very clear. Activation of the Gq subunit by CRH can then go on to activate the phospholipase $\mathrm{C} \beta$ pathway, which could activate the PKC pathway (Karteris et al. 2000). Our results demonstrated that progesterone production was up-regulated by Gö6976, a PKC inhibitor, and this increase could be reversed by the addition of exogenous CRH. These data support the hypothesis that CRH may act through a PKC-dependent pathway to inhibit progesterone production in placental trophoblast cells. Other signal pathways involved in CRH actions remained to be further investigated.

In human placenta, progesterone is formed by two steps. First, cholesterol is converted to pregnenolone by cytochrome P450scc (CYP11A1). Pregnenolone is then converted to progesterone by type $13 \beta$-hydroxysteroid dehydrogenase (HSD3B1; Tuckey 2005). We found that CRH significantly inhibited CYP11A1 and HSD3B1 mRNA expression in the cultured trophoblasts, which is consistent with a decrease in the concentration of progesterone, the product of these enzymes, in the culture media. These results suggest that CRH inhibits progesterone production by down-regulating these enzymes' gene expression. More recently, CRH has been shown to stimulate cortisol and DHEAS production by up-regulating the gene expression of the enzymes responsible for the synthesis of these steroids in fetal adrenal (Sirianni et al. 2005a,b).

Increasing evidence strongly suggests that placental CRH production is linked to the length of gestation in human (McLean et al. 1995). The mechanism by which placental CRH might precipitate parturition has remained unclear. Recent research has supported the view that parturition is a cascade of events that commences early in pregnancy and involves the mother, fetus, and placenta. Placental production of CRH is proposed as an early event regulating the cascade of the events (Smith et al. 2001). In most mammals, a pivotal event for the onset of parturition is changes in the maternal plasma concentrations of estrogens (which increase) and progesterone (which decrease) at the end of pregnancy (Norwitz et al. 1999). Although human 
parturition is not preceded by these systemic changes in estrogens and progesterone, changes in progesterone/ $17 \beta$-estradiol ratios (which decrease) occur during human parturition at term (Romero et al. 1988). Mazor et al. (1994) showed that progesterone/17 $\beta$-estradiol ratios decreased in preterm birth. More recently, we found that placental CRH stimulates 17ß-estradiol production by placental trophoblasts (You et al. 2006). In this study, we demonstrated that CRH locally produced in placenta inhibits progesterone production. Taken together, these results show that the effects of placental CRH on the production of sex steroid hormones might contribute to the changes in progesterone $/ 17 \beta$-estradiol ratios at term.

In conclusion, our results suggest that CRH locally produced in placenta exhibits a tonic inhibitory effect on progesterone production and progesterone biosynthesis pathway through a PKC-dependent pathway, which might be associated with changes in progesterone/17 $\beta$-estradiol ratios at term.

\section{Acknowledgements}

The authors wish to thank the nursing and medical staff of the delivery suites at Changhai Hospital for their cooperation in obtaining the placentas. This work was supported by Natural Science Foundation of China No. 30170982 and Program for Changjiang Scholars and Innovative Research Team in University. The authors declare that there is no conflict of interest that would prejudice the impartiality of this scientific work.

\section{References}

Chaudhary J, Bhattacharyya S \& Das C 1992 Regulation of progesterone secretion in human syncytiotrophoblast in culture by human chorionic gonadotropin. Journal of Steroid Biochemistry and Molecular Biology 42 425-432.

Clifton VL, Gu Q, Murphy VE, Schwartz J, Madsen G \& Smith R 2000 Localization and characterization of urocortin during human pregnancy. Placenta 21 782-788.

Feinman MA, Kliman HJ, Caltabiano S \& Strauss JF III 1986 8-Bromo$3^{\prime}, 5^{\prime}$-adenosine monophosphate stimulates the endocrine activity of human cytotrophoblasts in culture. Journal of Clinical Endocrinology and Metabolism 63 1211-1217.

Florio P, Lombardo M, Gallo R, Di Carlo C, Sutton S, Genazzani AR \& Petraglia F 1996 Activin A, corticotropin-releasing factor and prostaglandin F2 alpha increase immunoreactive oxytocin release from cultured human placental cells. Placenta 17 307-311.

Florio P, Franchini A, Reis FM, Pezzani I, Ottaviani E \& Petraglia F 2000 Human placenta, chorion, aminon and deciduas express different variants of corticotrophin-releasing hormone receptor messenger RNA. Placenta 21 32-37.

Ghizzoni L, Mastorakos G, Vottero A, Barreca A, Furlini M, Cesarone A, Ferrari B, Chrousos GP \& Bernasconi S 1997 Corticotropin-releasing hormone (CRH) inhibits steroid biosynthesis by cultured human granulosa-lutein cells in a CRH and interleukin-1 receptor-mediated fashion. Endocrinology 138 4806-4811.
Grammatopoulos DK, Dai Y, Randeva HS, Levine MA, Karteris E, Easton AJ \& Hillhouse EW 1999 A novel splice variant of the type-1 corticotropin releasing hormone $(\mathrm{CRH})$ receptor with a deletion in the 7 th transmembrane domain present in the human pregnant term myometrium and fetal membranes. Molecular Endocrinology 13 2189-2202.

Haluska GJ, Cook MJ \& Novy MJ 1997 Inhibition and augmentation of progesterone production during pregnancy: effect on parturition in rhesus monkeys. American Journal of Obstetrics and Gynecology 176 682-691.

Jeschke U, Mylonas I, Richter DU, Jeschke U, Mylonas I, Richter DU, Hocker I, Briese V, Makrigiannakis A \& Friese K 2005 Regulation of progesterone production in human term trophoblasts in vitro by CRH, ACTH and cortisol (prednisolone). Archives of Gynecology and Obstetrics 272 7-12.

Jones SA \& Challis JR 1990 Effect of corticotrophin-releasing hormone and adrenocorticotropin on prostaglandin output by human placenta fetal membranes. Gynecologic and Obstetric Investigation 29 $165-168$.

Karteris E, Grammatopoulos D, Randeva H \& Hillhouse EW 2000 Signal transduction characteristics of the corticotropin-releasing hormone receptors in the feto-placental unit. Journal of Clinical Endocrinology and Metabolism 85 1989-1996.

Karteris E, Vatish M, Hillhouse EW \& Grammatopoulos DK 2005 Preeclampsia is associated with impaired regulation of the placental nitric oxide-cyclic guanosine monophosphate pathway by corticotropin-releasing hormone (CRH) and CRH-related peptides. Journal of Clinical Endocrinology and Metabolism 90 3680-3687.

Kliman HJ, Nestler JE, Sermasi E \& Sanger JM III 1986 Purification, characterization and in vitro differentiation of cytotrophoblasts from human term placentae. Endocrinology 118 1567-1582.

McLean M, Bisits A, Davies J, Woods R, Lowry P \& Smith R 1995 A placental clock controlling the length of human pregnancy. Nature Medicine 1 460-463.

Mazor M, Hershkovitz R, Chaim W, Levy J, Sharony Y, Leiberman JR \& Glezerman M 1994 Human preterm birth is associated with systemic and local changes in progesterone/17 beta-estradiol ratios. American Journal of Obstetrics and Gynecology 171 231-236.

Mesiano S 2001 Roles of estrogen and progesterone in human parturition. Frontiers of Hormone Research 27 86-104.

Mosmann T 1983 Rapid colorimetric assay for cellular growth and survival: application to proliferation and cytotoxicity assays. Journal of Immunological Methods 65 55-63.

Ni X, Chan EC, Fitter JT \& Smith R 1997 Nitric oxide inhibits corticotropin-releasing hormone exocytosis but not biosynthesis by cultured human trophoblasts. Journal of Clinical Endocrinology and Metabolism 82 4171-4175.

Norwitz ER, Robinson JN \& Challis JRG 1999 The control of labor. New England Journal of Medicine 341 660-666.

Petraglia F, Sawchenko PE, Rivier J \& Vale W 1987 Evidence for local stimulation of ACTH secretion by corticotrophin-releasing factor in human placenta. Nature 328 717-719.

Quartero HW \& Fry CH 1989 Placental corticotrophin releasing factor may modulate human parturition. Placenta 10 439-443.

Riley SC, Walton JC, Herlick JM \& Challis JRG 1991 The localization and distribution of corticotropin-releasing hormone in the human placenta and fetal membranes throughout gestation. Journal of Clinical Endocrinology and Metabolism 72 1001-1007.

Rodway M, Zhou FZ, Benoit J, Yuen BH \& Leung PC 1988 Differential effects of 8-bromo-cyclic AMP on human chorionic gonadotropin (hCG), progesterone and estrogen production by term placental cells. Life Science 43 1451-1458.

Romero R, Scoccia B, Mazor M, Wu YK \& Benveniste R 1988 Evidence for a local change in the progesterone/estrogen ratio in human parturition at term. American Journal of Obstetrics and Gynecology 159 $657-660$.

Sasaki A, Shinkawa O, Margioris AN, Liotta AS, Sato S, Murakami O, Go M, Shimizu Y, Hanew K \& Yoshinaga K 1987 Immunoreactive 
corticotropin-releasing hormone in human placenta during pregnancy, labor and delivery. Journal of Clinical Endocrinology and Metabolism 64 224-229.

Selinger M, MacKenzie IZ, Gillmer MD, Phipps SL \& Ferguson J 1987 Progesterone inhibition in mid-trimester termination of pregnancy: physiological and clinical effects. British Journal of Obstetrics and Gynaecology 94 1218-1222.

Sirianni R, Mayhew BA, Carr BR, Parker CR Jr \& Rainey WE $2005 a$ Corticotropin-releasing hormone $(\mathrm{CRH})$ and urocortin act through type $1 \mathrm{CRH}$ receptors to stimulate dehydroepiandrosterone sulfate production in human fetal adrenal cells. Journal of Clinical Endocrinology and Metabolism 90 5393-5400.

Sirianni R, Rehman KS, Carr BR, Parker CR Jr \& Rainey WE $2005 b$ Corticotropin-releasing hormone directly stimulates cortisol and the cortisol biosynthetic pathway in human fetal adrenal cells. Journal of Clinical Endocrinology and Metabolism 90 279-285.

Smith R, Mesiano S, Chan E-C, Brown S \& Jaffe RB 1998 Corticotropinreleasing hormone directly stimulates dehydroepiandrosterone sulfate secretion by human fetal adrenal cortical cells. Journal of Clinical Endocrinology and Metabolism 83 2916-2920.
Smith R, Mesiano S \& McGrath S 2001 Hormone trajectories leading to human birth. Regulatory Peptides 108 159-164.

Sun K, Smith R \& Robinson PJ 1994 Basal and KCl-stimulated corticotropin-releasing hormone release from human placental syncytiotrophoblasts is inhibited by sodium nitroprusside. Journal of Clinical Endocrinology and Metabolism 79 519-524.

Tuckey RC 2005 Progesterone synthesis by human placenta. Placenta 26 273-281.

Wadhwa PD, Porto M, Garite TJ, Chicz-DeMet A \& Sandman CA 1998 Maternal corticotropin-releasing hormone levels in the early third trimester predict length of gestation in human pregnancy. American Journal of Obstetrics and Gynecology 179 1079-1085.

You X, Yang R, Tang X, Gao L \& Ni X 2006 Corticotropin-releasing hormone stimulates estrogen biosynthesis in cultured human placental trophoblasts. Biology of Reproduction 74 1067-1072.

Received 16 July 2006

Accepted 29 September 2006 